\title{
INFLUENCE OF SUPPLEMENTED GENISTEIN AND DAIDZEIN ON THE PRODUCTION PERFORMANCE AND EGG STRUCTURE DURING THE FIRST EGG-LAYING CYCLE
}

\author{
Natasha Gjorgovska $^{1^{*}}$, Kiril Filev ${ }^{2}$, Svetlana Grigorova ${ }^{3}$ \\ ${ }^{1}$ Institute of Animal Science, "Ss. Cyril and Methodius" University in Skopje, \\ Blvd. Ilinden 92a, Skopje, North Macedonia \\ ${ }^{2}$ Faculty of Agricultural Sciences and Food, "Ss Cyril and Methodius" University in Skopje, \\ bul. Aleksandar Makedonski bb, 1000 Skopje, Macedonia \\ ${ }^{3}$ Institute of Animal Sciences, AAS, Spirka Pochivka, 2232 Kostinbrod, Bulgaria \\ *natashagjorgovska@gmail.com
}

\begin{abstract}
A b s t r a c t: The process of egg formation and egg quality depend on several biomechanisms that can be modifed by various environmental, genetic and nutritional components. This experiment was performed to estimate the influence of supplementation with dietary isoflavones (daidzein and genistein) in feed on the production performance and egg structure during the first egg production period. Eighty ISA Brown laying hens were randomly divided into four groups, 20 birds per group, and surveyed during 3 consecutive periods (27-42 wks, 43-60 wks and over $60 \mathrm{wks}$ ). Concerning diet supplemented with isoflavones (genistein and daidzein), the egg weight was statistically different compared with the control group (confidence interval of 95\%) in all the 3 periods of the experiment. The yolk:white ratio was significantly higher in the control group compared with the groups fed with 1000, 2000 and $3000 \mathrm{mg}$ of isoflavones per $1 \mathrm{~kg}$ of feed in the periods of $27-42$ wks and $43-60$ wks $(\mathrm{P}<0.05)$.
\end{abstract}

Key words: soy isoflavones; laying hens; egg structure

\section{ВЛИЈАНИЕ НА ДОДАВАЊЕТО НА ГЕНИСТЕИН И ДАИДЗЕИН НА ПРОИЗВОДСТВОТО И СТРУКТУРАТА НА ЈАЈЦАТА ВО ТЕКОТ НА ПРВИОТ ЈАЈЦЕНОСЕН ПЕРИОД}

\begin{abstract}
А п с т р а к т: Процесот на формирање на јајцето и квалитетот на јајцето зависи од неколку биомеханизми кои можат да се модифицираат од разни компоненти на животната средина, генетските и исхраната. Овој експеримент беше спроведен за да се оцени влијанието на употребата на диетални изофлавони (даидзеин и генистеин) во добиточната храна на производните перформанси и структурата на јајцата во текот на првиот период на производство на јајца. Осумдесет кокошки несилки ИСА Браун беа поделени во четири групи, 20 птици по група и беа испитувани во текот на 3 последователни периоди (27-42 недели, 43-60 недели и над 60 недели). Што се однесува до исхраната надополнета со изофлавони (генистеин и даидзеин, тежината на јајцето беше статистички различна во споредба со контролната група (сингнификантност од 95\%) во сите 3 периоди на експериментот. Односот на жолчка: белтокот беше значително повисок во контролната група во споредба со групите хранети со 1000, 2000 и 3000 мг изофлавони на 1 кг добиточна храна во периодите од 27-42 недели и 43-60 недели $(\mathrm{P}<0,05)$.
\end{abstract}

Клучни зборови: изофлавони од соја; кокошки несилки, структура на јајцето

\section{INTRODUCTION}

The process of egg formation and subsequent egg quality is dependent on several biomechanisms that can be altered by various environmental, genetic and nutritional components (Chukuwuka et al., 2011). Nutritional manipulation and genetic selection for egg size and production may lead to changes 
in egg components. Poultry eggs are one of the most attractive targets for nutrition modulation, owing to the extraordinary responsiveness of most of its properties to dietary factors (Wang et al., 2017). Inclusion of the soybean meal which is the good source of protein and isoflavones in the poultry feed rapidly increased in recent years. The isoflavones are potential dietary supplement that may affect the growth (Jiang et al., 2007; Gjorgovska et al., 2014), the productive performance (Gjorgovska et al., 2016), deposition in the egg yolk (Saitoh et al., 2001; Lin et al., 2004; Gjorgovska and Kiril, 2013), reducing the egg yolk cholesterol (Gjorgovska et al., 2015) and positive and some negative impact.

Therefore, the purpose of this experiment was to evaluate the effect of isoflavones on the productive performance and egg quality during first egg laying cycle.

\section{MATERIAL AND METHODS}

Eighty ISA Brown laying hens were randomly divided into four groups, 20 birds per group and estimate during 3 periods $(27-42$ wks, $43-60$ wks and Over $60 \mathrm{wks})$. The hens were housed in laying cages ( 2 birds per cage) in a standard poultry house. The laying hens were fed basal feed (control group) and the supplemented feed with 1000, 2000 and $3000 \mathrm{mg}$ isoflavones per $\mathrm{kg}$ feed. Water was offered for ad libitum consumption throughout the experiment, which was conducted for 12 months. The experimental feed was supplemented with a concentrated product, $40 \%$ isoflavones, produced by the North China Pharmaceutical Corporation. The isoflavone composition of the product is presented in Table 1.

Table 1

\begin{tabular}{cc} 
Composition of the $40 \%$ isoflavone produn \\
\cline { 2 - 2 } Isoflavone & $\%$ \\
\hline 1. Genistin & 7.30 \\
2. Genistein & 1.26 \\
3. Daidzin & 22.12 \\
4. Daidzein & 1.74 \\
5. Glycitin & 8.01 \\
6. Glycitein & 0.45 \\
Total & 40.88 \\
\hline
\end{tabular}

Table 2

Composition and nutritive value of the basal feed $(B F)$

\begin{tabular}{|c|c|c|c|c|}
\hline Ingredient, $\mathrm{g} / \mathrm{kg}$ & 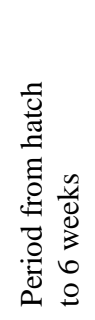 & 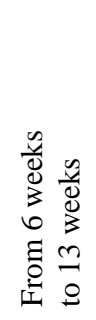 & 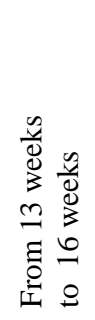 & 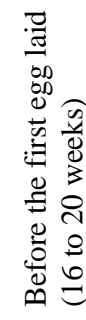 \\
\hline Maize & 562.3 & 603.9 & 607.2 & 552.5 \\
\hline Soybean meal $44 \%$ & 188.4 & 187.8 & 74.1 & 168.9 \\
\hline Sunflower meal $33 \%$ & 153.4 & 65.0 & 146.8 & 150.0 \\
\hline Fish meal & 50.0 & 25.7 & - & - \\
\hline Wheat bran & - & 73.4 & 127.8 & 50.0 \\
\hline Soybean oil & 3.5 & - & - & 7.0 \\
\hline Methionine 99\% & 0.7 & 0.2 & 0.3 & 0.7 \\
\hline L-lysine & 1.0 & 0.7 & 0.8 & 0.6 \\
\hline Calcium carbonate & 16.4 & 19.8 & 18.2 & 43.9 \\
\hline Mono calcium phosphate & 14.2 & 13.2 & 13.8 & 14.5 \\
\hline $\mathrm{NaHCO}_{3}$ & - & - & 1.0 & 1.6 \\
\hline Minezyl (Zeolites) & 3.0 & 3.0 & 3.0 & 3.0 \\
\hline Salt & 2.2 & 2.2 & 2.1 & 2.4 \\
\hline Mineral premix & 5.0 & 5.0 & 5.0 & 5.0 \\
\hline Total & 1000 & 1000 & 1000 & 1000 \\
\hline
\end{tabular}

Chemical composition, calculated

\begin{tabular}{lrrrr}
\hline Dry matter, g/kg & 89.24 & 89.04 & 88.95 & 89.42 \\
Metabolic energy, kcal/kg & 2900 & 2800 & 2750 & 2750 \\
Crude protein, g/kg & 21.44 & 18.20 & 14.81 & 17.50 \\
Crude fat, g/kg & 3.14 & 2.86 & 2.89 & 3.13 \\
Calcium, g/kg & 1.05 & 1.10 & 1.00 & 2.00 \\
Phosphorus (available), g/kg & 0.78 & 0.74 & 0.81 & 0.78 \\
Lysine, g/kg & 1.20 & 1.00 & 0.65 & 0.85 \\
DL Methonine, g/kg & 0.53 & 0.39 & 0.33 & 0.41 \\
Methionine + cystine, g/kg & 0.83 & 0.67 & 0.57 & 0.68 \\
& & & & \\
Soybean meal isoflavones, mg/kg* & 43.33 & 43.19 & 17.04 & 38.85
\end{tabular}

*Native isoflavones in soybean meal

Egg collection and egg quality analysis: The number of produced eggs was monitored every day. The egg structure parameters (egg weight, white weight, yolk weight and eggshell weight) and their percentage in the egg weight was measured on 6 
randomly selected eggs 3 times during the experiment (every 15th day) on balance with $0.1 \mathrm{~g}$ accuracy. The eggs were weighed, and then yolks were separated with an egg separator and weighed. The shell was wiped clean and weighed. The albumen weight was calculated by subtracting yolk and shell weight from total egg weight.

\section{RESULTS AND DISCUSSION}

Hen's weight, egg production and feed intake of laying hens in the four groups are shown in Table 3. The egg production of laying hens during the first egg laying cycle was similar across the treatment $(P$ $>0.05)$.

Table 3

Supplemented genistein and daidzein's influence on the laying performance during the first egg-laying cycle

\begin{tabular}{|c|c|c|c|c|c|c|c|c|c|c|c|c|}
\hline & \multicolumn{4}{|c|}{$27-42 w k s$} & \multicolumn{4}{|c|}{$43-60$ wks } & \multicolumn{4}{|c|}{ Over 60 wks } \\
\hline & 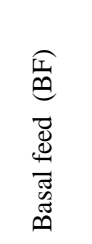 & 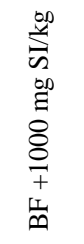 & 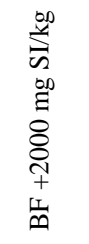 & 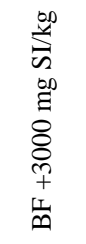 & 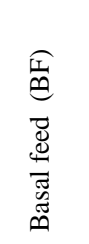 & $\begin{array}{l}\infty \\
\stackrel{\infty}{1} \\
\sim \\
0 \\
\vdots \\
\vdots \\
8 \\
8 \\
0 \\
+ \\
\frac{1}{\infty}\end{array}$ & 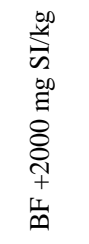 & 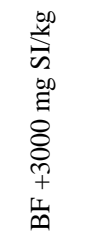 & 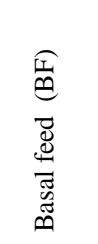 & 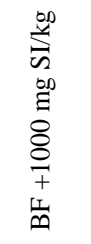 & 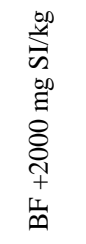 & 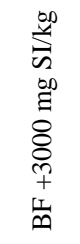 \\
\hline Number of hens & 20 & 20 & 20 & 20 & 20 & 20 & 20 & 20 & 20 & 20 & 20 & 20 \\
\hline \multicolumn{13}{|l|}{ Hen's weight } \\
\hline - initial, g & $\begin{array}{l}1674 \\
\pm 128\end{array}$ & $\begin{array}{l}1688 \\
\pm 122\end{array}$ & $\begin{array}{c}1660 \\
\pm 97\end{array}$ & $\begin{array}{l}1680 \\
\pm 155\end{array}$ & $\begin{array}{l}1781 \\
\pm 109\end{array}$ & $\begin{array}{l}1800 \\
\pm 111\end{array}$ & $\begin{array}{l}1760 \\
\pm 105\end{array}$ & $\begin{array}{l}1768 \\
\pm 165\end{array}$ & $\begin{array}{c}1928 \pm \\
183\end{array}$ & $\begin{array}{l}1809 \\
\pm 193\end{array}$ & $\begin{array}{l}1934 \\
\pm 169\end{array}$ & $\begin{array}{l}1883 \\
\pm 180\end{array}$ \\
\hline - final, $\mathrm{g}$ & $\begin{array}{l}1772 \\
\pm 111\end{array}$ & $\begin{array}{l}1774 \\
\pm 110\end{array}$ & $\begin{array}{l}1756 \\
\pm 109\end{array}$ & $\begin{array}{l}1761 \\
\pm 170\end{array}$ & $\begin{array}{l}2049 \\
\pm 204\end{array}$ & $\begin{array}{l}1842 \\
\pm 256\end{array}$ & $\begin{array}{l}2063 \\
\pm 204\end{array}$ & $\begin{array}{l}2016 \\
\pm 204\end{array}$ & $\begin{array}{l}1940 \\
\pm 176\end{array}$ & $\begin{array}{l}1851 \\
\pm 220\end{array}$ & $\begin{array}{l}1919 \\
\pm 168\end{array}$ & $\begin{array}{l}1860 \\
\pm 178\end{array}$ \\
\hline Egg, production, \% & 92.60 & 88.18 & 91.41 & 95.00 & 83.00 & 76.80 & 75.06 & 80.60 & 74.31 & 65.60 & 58.70 & 66.27 \\
\hline \multicolumn{13}{|l|}{ Feed consumption } \\
\hline - daily consumption, $\mathrm{g}$ & 110 & 110 & 110 & 110 & 115 & 115 & 115 & 115 & 120 & 120 & 120 & 120 \\
\hline
\end{tabular}

In Table 4 are presented the results of the egg parameters during the first egg laying cycle of the laying hens fed with diet supplemented with different dose of genistein and daidzein. Nutritional manipulation for egg size and production may lead to changes in egg components. Isoflavones inclusion into the feeding ration of laying hens improved the pre-ovulation follicular development (Liu and Zhang, 2008), increased the egg weight and the laying performance (Guo-zhen and $\mathrm{Li}, 2014$ ), increased the eggshell thickness and strength and raised the level of calcium in the shell (Etxeberria et al., 2013). This experiment was carried out to analyze the egg structure parameters of eggs produced by Hisex Brown laying hens fed with diet with different supplements inclusion. The egg weight during the trial was significantly different $(\mathrm{P}<0.05)$ in comparison of the control group and other groups of laying hens fed with 1000, 2000 and $3000 \mathrm{mg} / \mathrm{kg}$ supplemented genistein and daidzein. Egg weights were the greatest in laying hens supplemented with genistein and daidzein, whereas they were the lowest in laying hens unsupplemented with genistein and daidzein (Table 4). Similar trends were also noted in white weights and yolk:white ratio in response to the dietary treatments, while there was no differences in egg yolk egg shell, egg percentage (white, yolk and shell) and edible portion $(P>0.05)$. The present study provided evidence that genistein and daidzein significantly effected the egg weignt and the egg white and yolk:white ratio during the first year period of egg laying in ISA hens (Table 2). The improvement of the two egg quality characteristics (egg weight and white weight) was therefore probably due to increases the albumen formation which is the biggest egg component. Previous studies from Saitoh et al. (2001) and Zhao et al. (2005) have also shown that soy isoflavone supplementation improved egg production and egg quality in poultry. In the experiment performed by Shi et al. have been shown that isoflavones added as supplements in the diet of laying hens during the later 
period of laying, after the peak production, significantly affect egg production, egg weight and feed conversion.

The highest value $(44.00 \pm 5.75)$ of the yolk: white ratio was noticed in the eggs of the control group $(\mathrm{P}<0.05)$ during the period from $43^{\text {rd }}$ week to $60^{\text {st }}$ week laying hen's age. Several factors affect total edible portion and yolk:white ratio. Age of hen, size of eggs, nutrition, and strain can affect these parameters (Ahmadi and Rahimi, 2011; Roberts, 2004; Galea, 2011).

Table 4

Supplemented genistein and daidzein's influence on the egg quality during the first egg-laying cycle

\begin{tabular}{|c|c|c|c|c|c|c|c|c|c|c|c|c|}
\hline & \multicolumn{4}{|c|}{$27-42$ wks } & \multicolumn{4}{|c|}{$43-60$ wks } & \multicolumn{4}{|c|}{ Over 60 wks } \\
\hline & 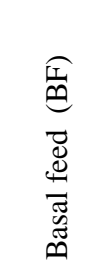 & 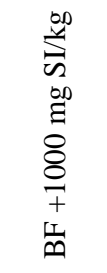 & 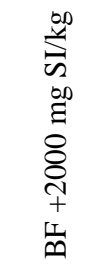 & 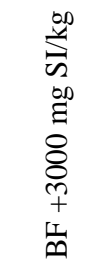 & 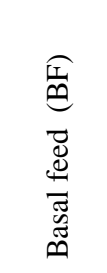 & 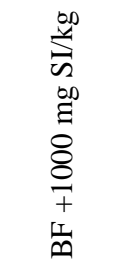 & 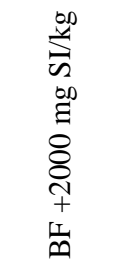 & 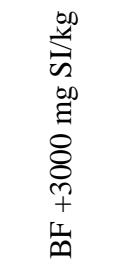 & 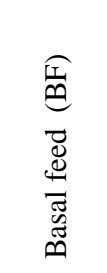 & 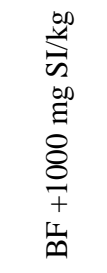 & 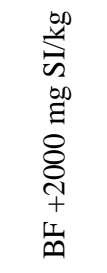 & 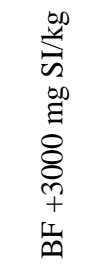 \\
\hline Egg, g & $\begin{array}{l}59.56 \\
\pm 5.47^{\mathrm{a}}\end{array}$ & $\begin{array}{c}63.50 \\
\pm 4.54^{\mathrm{b}}\end{array}$ & $\begin{array}{c}61.89 \\
\pm 5.93^{\mathrm{b}}\end{array}$ & $\begin{array}{c}63.34 \\
\pm 5.90^{\mathrm{b}}\end{array}$ & $\begin{array}{c}63.71 \\
\pm 3.88^{\mathrm{a}}\end{array}$ & $\begin{array}{c}67.18 \\
\pm 5.27^{\mathrm{b}}\end{array}$ & $\begin{array}{c}68.76 \\
\pm 4.76^{\mathrm{b}}\end{array}$ & $\begin{array}{c}66.19 \\
\pm 4.36^{\mathrm{b}}\end{array}$ & $\begin{array}{l}65.51 \\
\pm 2.95^{\mathrm{a}}\end{array}$ & $\begin{array}{r}70.80 \\
\pm 3.62^{\mathrm{b}}\end{array}$ & $\begin{array}{c}68.33 \\
\pm 5.08^{\mathrm{b}}\end{array}$ & $\begin{array}{c}67.53 \\
\pm 4.90^{\mathrm{b}}\end{array}$ \\
\hline White, $\mathrm{g}$ & $\begin{array}{l}38.02 \\
\pm 3.48\end{array}$ & $\begin{array}{l}41.17 \\
\pm 3.21\end{array}$ & $\begin{array}{l}39.90 \\
\pm 4.21\end{array}$ & $\begin{array}{l}40.81 \\
\pm 3.90\end{array}$ & $\begin{array}{c}39.70 \\
\pm 3.54 \mathrm{a}\end{array}$ & $\begin{array}{c}41.95 \\
\pm 4.23^{\mathrm{ab}}\end{array}$ & $\begin{array}{c}43.19 \\
\pm 3.75^{b}\end{array}$ & $\begin{array}{c}41.75 \\
\pm 3.10^{\mathrm{ab}}\end{array}$ & $\begin{array}{l}41.80 \\
\pm 1.86^{\mathrm{a}}\end{array}$ & $\begin{array}{l}45.24 \\
\pm 3.46^{\mathrm{b}}\end{array}$ & $\begin{array}{c}43.49 \\
\pm 3.62^{\mathrm{b}}\end{array}$ & $\begin{array}{c}43.47 \\
\pm 3.68^{\mathrm{b}}\end{array}$ \\
\hline Yolk, g & $\begin{array}{l}14.86 \\
\pm 2.05\end{array}$ & $\begin{array}{l}15.30 \\
\pm 1.68\end{array}$ & $\begin{array}{l}15.09 \\
\pm 1.90\end{array}$ & $\begin{array}{l}15.49 \\
\pm 1.95\end{array}$ & $\begin{array}{l}17.30 \\
\pm 1.29\end{array}$ & $\begin{array}{l}17.73 \\
\pm 1.29\end{array}$ & $\begin{array}{l}18.46 \\
\pm 1.89\end{array}$ & $\begin{array}{l}17.43 \\
\pm 1.67\end{array}$ & $\begin{array}{l}16.61 \\
\pm 1.37\end{array}$ & $\begin{array}{l}18.17 \\
\pm 1.09\end{array}$ & $\begin{array}{l}17.39 \\
\pm 1.40\end{array}$ & $\begin{array}{l}16.87 \\
\pm 1.41\end{array}$ \\
\hline Shell, g & $\begin{array}{c}6.68 \\
\pm 0.61\end{array}$ & $\begin{array}{c}7.03 \\
\pm 0.56\end{array}$ & $\begin{array}{c}6.91 \\
\pm 0.66\end{array}$ & $\begin{array}{c}7.06 \\
\pm 0.66\end{array}$ & $\begin{array}{c}6.71 \\
\pm 0.85\end{array}$ & $\begin{array}{c}7.50 \\
\pm 0.66\end{array}$ & $\begin{array}{c}7.11 \\
\pm 0.91\end{array}$ & $\begin{array}{c}7.00 \\
\pm 0.48\end{array}$ & $\begin{array}{c}7.10 \\
\pm 0.67\end{array}$ & $\begin{array}{c}7.39 \\
\pm 0.70\end{array}$ & $\begin{array}{c}7.45 \\
\pm 0.70\end{array}$ & $\begin{array}{c}7.20 \\
\pm 0.65\end{array}$ \\
\hline White, \% & $\begin{array}{l}63.87 \\
\pm 1.95\end{array}$ & $\begin{array}{l}64.83 \\
\pm 1.84\end{array}$ & $\begin{array}{l}64.44 \\
\pm 2.20\end{array}$ & $\begin{array}{l}64.44 \\
\pm 1.64\end{array}$ & $\begin{array}{l}62.23 \\
\pm 2.42\end{array}$ & $\begin{array}{l}62.37 \\
\pm 2.22\end{array}$ & $\begin{array}{l}62.78 \\
\pm 2.52\end{array}$ & $\begin{array}{l}63.07 \\
\pm 1.59\end{array}$ & $\begin{array}{l}63.81 \\
\pm 1.95\end{array}$ & $\begin{array}{l}63.83 \\
\pm 2.09\end{array}$ & $\begin{array}{l}63.62 \\
\pm 1.71\end{array}$ & $\begin{array}{l}64.34 \\
\pm 1.78\end{array}$ \\
\hline Yolk, \% & $\begin{array}{l}24.89 \\
\pm 1.82\end{array}$ & $\begin{array}{l}24.08 \\
\pm 1.85\end{array}$ & $\begin{array}{l}24.39 \\
\pm 2.02\end{array}$ & $\begin{array}{l}24.41 \\
\pm 1.59\end{array}$ & $\begin{array}{l}27.25 \\
\pm 2.59\end{array}$ & $\begin{array}{l}26.46 \\
\pm 1.73\end{array}$ & $\begin{array}{l}26.88 \\
\pm 2.41\end{array}$ & $\begin{array}{l}26.31 \\
\pm 1.47\end{array}$ & $\begin{array}{l}25.34 \\
\pm 1.64\end{array}$ & $\begin{array}{l}25.71 \\
\pm 1.71\end{array}$ & $\begin{array}{l}25.47 \\
\pm 1.24\end{array}$ & $\begin{array}{l}25.00 \\
\pm 1.64\end{array}$ \\
\hline Shell, \% & $\begin{array}{l}11.24 \\
\pm 0.83\end{array}$ & $\begin{array}{l}11.08 \\
\pm 0.69\end{array}$ & $\begin{array}{l}11.18 \\
\pm 0.64\end{array}$ & $\begin{array}{l}11.15 \\
\pm 0.70\end{array}$ & $\begin{array}{l}10.52 \\
\pm 1.06\end{array}$ & $\begin{array}{l}11.18 \\
\pm 0.80\end{array}$ & $\begin{array}{l}10.34 \\
\pm 1.12\end{array}$ & $\begin{array}{l}10.61 \\
\pm 0.87\end{array}$ & $\begin{array}{l}10.83 \\
\pm 0.74\end{array}$ & $\begin{array}{l}10.46 \\
\pm 1.14\end{array}$ & $\begin{array}{l}10.91 \\
\pm 0.73\end{array}$ & $\begin{array}{l}10.66 \\
\pm 0.67\end{array}$ \\
\hline $\begin{array}{l}\text { Edible } \\
\text { portion, \% }\end{array}$ & $\begin{array}{l}88.76 \\
\pm 0.83\end{array}$ & $\begin{array}{l}88.92 \\
\pm 0.69\end{array}$ & $\begin{array}{l}88.82 \\
\pm 0.64\end{array}$ & $\begin{array}{l}88.85 \\
\pm 0.70\end{array}$ & $\begin{array}{l}89.48 \\
\pm 1.06\end{array}$ & $\begin{array}{l}88.82 \\
\pm 0.80\end{array}$ & $\begin{array}{l}89.66 \\
\pm 1.12\end{array}$ & $\begin{array}{l}89.39 \\
\pm 0.87\end{array}$ & $\begin{array}{l}89.17 \\
\pm 0.74\end{array}$ & $\begin{array}{l}89.54 \\
\pm 1.14\end{array}$ & $\begin{array}{l}89.09 \\
\pm 0.73\end{array}$ & $\begin{array}{l}89.34 \\
\pm 0.67\end{array}$ \\
\hline Yolk:white & $\begin{array}{c}39.09 \\
\pm 4.06^{\mathrm{a}}\end{array}$ & $\begin{array}{c}37.25 \\
\pm 3.88^{b}\end{array}$ & $\begin{array}{c}37.99 \\
\pm 4.39^{\mathrm{b}}\end{array}$ & $\begin{array}{c}37.97 \\
\pm 3.38^{b}\end{array}$ & $\begin{array}{r}44.00 \\
\pm 5.75^{\mathrm{a}}\end{array}$ & $\begin{array}{c}42.56 \\
\pm 4.28 \mathrm{~b}\end{array}$ & $\begin{array}{c}43.00 \\
\pm 5.26 \mathrm{~b}\end{array}$ & $\begin{array}{c}41.79 \\
\pm 3.27 \mathrm{~b}\end{array}$ & $\begin{array}{l}39.79 \\
\pm 3.63\end{array}$ & $\begin{array}{l}40.38 \\
\pm 3.85\end{array}$ & $\begin{array}{l}40.11 \\
\pm 2.96\end{array}$ & $\begin{array}{r}38.95 \\
\pm 3.57\end{array}$ \\
\hline
\end{tabular}

Values are means \pm S.D

${ }^{\mathrm{a}-\mathrm{b}}$ Different superscripts within collumns are significantly different $(\mathrm{P}<0.05)$.

\section{CONCLUSIONS}

In conclusion, data obtained in the present study showed that suitable and available genistein and daidzein supplements could improve egg weight and white weight. The egg weight and egg white during the trial was significantly different $(\mathrm{P}<0.05)$ in comparison of the control group and other groups of laying hens fed with 1000, 2000 and $3000 \mathrm{mg} / \mathrm{kg}$ supplemented genistein and daidzein. Egg weights and white were the greatest in laying hens supplemented with genistein and daidzein, whereas they were the lowest in laying hens unsupplemented with genistein and daidzein

These findings indicated that the genistein and daidzein could be a very effective additive to improve laying performance and egg quality in the birds during the whole first egg laying period.

\section{REFERENCES}

[1] Ahmadi, F., Rahimi F.: Factors affecting quality and quantity of egg production in laying hens: Review. World Applied Sciences Journal, 12 (3), 372-384 (2003). 
[2] Chukwuka, O. K., Okoli, I.C., Okeudo, N.J., Udedibie, A.B.I., Ogbuewu, I.P., Aladi, N.O., Iheshiulor, O.O.M., Omede, A.A.: Egg quality defects in poultry management and food safety. Asian Journal of Agricultural Research, 5 (1),1816 (2011).

[3] Etxeberria, U., Fernández-Quintela, A., Milagro, F.I., Aguirre, L.. Martínez, J.A., Portillo, M.P.: Impact of Polyphenols and Polyphenol-Rich Dietary Sources on Gut Microbiota Composition. J. Agric. Food Chem. 61, 9517 9533 (2013).

[4] Galea, F.: Nutrition and food management and their influence on egg quality. In: Proccedings XLVIII Simposio Científico de Avicultura, Santiago de Compostela 5 al 7 de octubre de 201, 2011.

[5] Gjorgovska, N., Filev, K., Pavlova, V., Levkov, V.: Effects of the soy isoflavones on the growth and the exterior development of the ISA Brown pullets. Emirates Journal of Food and Agriculture, Vol. 26 (9), 822-827 (2014).

[6] Gjorgovska, N., Filev, K., Levkov V., Kostov, V., Nastova, R., Gjorgjievski, S., Grigorova, S.: Effects of isoflavones in feed on plasma estradiol concentration and productive perforamces in laying hens. Iranian Journal of Applied Animal Science, Vol. 6 (3), 691-695 (2016).

[7] Gjorgovska, N., Filev, K., Levkov, V., Nastova, R.: Effect of supplemented isoflavones in feed on plasma and egg cholesterol concentration in ISA Brown layers. Veterinarija ir Zootechnika, Vol. 70 (92),16-21 (2015).

[8] Gjorgovska, N., Filev K.: Transfer Of Daidzein And Genistein From Feed Into The Egg Yolk of Hens. Journal of Animal and Feed Sciences, 22, 144-148 (2013).

[9] Guo-zhen, J., Li, W.: Effect of Daidzein on Ileum Microflora Biodiversity in Hy-Line Variety Brown Layers. $J$. Northeast Agric. Univ. 21, 31-36 (2014).
[10] Jiang, Z.Y., Jiang, S.Q., Lin, Y.C., Xi, P.B., Yu, D.Q., Wu, T.X.: Effects of soybean isoflavone on growth performance, meat quality, and antioxidation in male broilers. Poultry Sci. 86:1356-1362 (2007).

[11] Wang, J., Yue, H., Wu, S.-G., Zhang, H., Qi, G.-H.: Nutritional modulation of health, egg quality and environmental pollution of the layers. Animal Nutrition Volume 3, Issue 2, pp. 91-96 (2017).

[12] Lin, F., Wu, J., Abdelnabi, M.A., Ottinger, M.A., Giusti, M.M.: Effects of dose and glycosylation on the transfer of genistein into the eggs of the Japanese quail (Coturnix japonica). J. Agr. Food Chem. 52, pp. 2397-2403 (2004).

[13] Liu, H.Y.; Zhang, C.Q.: Effects of daidzein on messenger ribonucleic Acid expression of gonadotropin receptors in chicken ovarian follicles. Poult. Sci. 87, pp. 541-545 (2008).

[14[ Roberts, R. J.: Factors affecting egg internal quality and egg shell quality in laying hens. The Journal of Poultry Science, 41 (3), pp. 161-177 (2004).

[15] Saitoh, S., Sato, T., Harada, H., Takita, T.: Transfer of soy isoflavone into the egg yolk of chickens. Biosci. Biotechnol. Biochem. 65, pp. 2220-2225 (2001).

[16] Shi, S.R., Gu, H., Chang, L.L., Wang, Z.Y., Tong, H.B., Zou, J,M.: Safety evaluation of daidzain in laying hens: Part I. Effects on laying performance, clinical blood parameters, and organs development. Food Chem Toxicol, 55 , pp. 684-88 (2013).

[17] Zhao, R.Q., Zhou, Y.C., Ni, Y.D., Lu, L.Z., Tao, Z.R., Chen, W.H.. Chen J.: Effect of daidzein on egg-laying perform-ance in Shaoxing duck breeders during different stages of the egg production cycle. Br. Poult. Sci. 46, pp. 175-181 (2005). 
